\title{
PEMELIHARAAN LARVA KERAPU RAJA SUNU (Plectropomus laevis) DENGAN PERBEDAAN AWAL PEMBERIAN PAKAN BUATAN
}

\author{
Bejo Slamet", Titiek Aslianti, Ketut Maha Setiawati, Wawan Andriyanto, dan Afifah Nasukha \\ Balai Besar Penelitian dan Pengembangan Budidaya Laut
}

(Naskah diterima: 4 September 2015; Revisi final: 4 November 2015; Disetujui publikasi: 9 November 2015)

\begin{abstract}
ABSTRAK
Ikan kerapu raja sunu (Plectropomus laevis) merupakan komoditas ekspor yang bernilai ekonomis tinggi di pasar Asia, namun stoknya di alam sudah langka. Pemberian pakan buatan dalam pemeliharaan larvanya telah dilakukan, namun waktu respon awal larva terhadap pakan buatan secara tepat belum diketahui. Penelitian ini bertujuan untuk mengetahui waktu awal pemberian pakan buatan yang efektif pada pemeliharaan larvanya. Tiga perlakuan pemberian pakan buatan yang diuji yaitu mulai umur 7 hari (D-7) (A), D-10 (B), dan D-13 (C). Parameter yang diamati meliputi perkembangan panjang total, sintasan larva, jumlah rotifer dalam lambung dan histologi organ pencernaan larva. Penelitian berlangsung sampai larva berumur 43 hari, menggunakan rancangan acak kelompok (RAK) dengan tiga kelompok waktu untuk setiap perlakuan. Hasil penelitian menunjukkan bahwa perbedaan waktu awal pemberian pakan buatan berpengaruh terhadap sintasan dan pertumbuhan larva. Panjang total dan sintasan larva umur 43 hari yang tertinggi dicapai pada perlakuan B yaitu $29,3 \mathrm{~mm} \pm 0,36 \mathrm{~mm}$ dan $2,61 \% \pm 0,21 \%$; diikuti oleh perlakuan C dengan nilai $28,0 \mathrm{~mm} \pm 0,85 \mathrm{~mm}$ dan $1,55 \% \pm 0,18 \%$; dan yang terendah pada perlakuan $\mathrm{A}$ adalah $27,0 \mathrm{~mm} \pm 0,25 \mathrm{~mm}$ dan $0,85 \% \pm 0,13 \%$. Data ini menunjukkan bahwa waktu awal pemberian pakan buatan yang terbaik adalah mulai larva berumur 10 hari.
\end{abstract}

KATA KUNCI: kerapu raja sunu, larva, pakan buatan

ABSTRACT: Larval rearing of blacksaddled coral grouper (Plectropomus laevis) with different initial feeding time with artificial diet. By: Bejo Slamet, Titiek Aslianti, Ketut Maha Setiawati, Wawan Andriyanto, and Afifah Nasukha

Blacksaddled coral grouper (Plectropomus laevis) is an export commodity and has high economic value in Asian markets. Wild population of this grouper was already threatened. Trial on aplication of artificial diet on Blacksaddled coral grouper larval rearing in hatchery have been conducted, however the exactly time for the initial feeding response not knew yet. The purpose of the present study is to know the effect of initial feeding with artificial feed on survival rate and growth of Blacksaddled coral grouper larvae. Three feeding time experiments have been conducted namely: artificial feed start from 7 days old larvae (D-7) (A), D-10 (B) and D-13 (C). The experiment was conducted in three block time series per treatment. A block randomized design was used in the study and data were analized by Anova. Result of the experiment showed that the different times of the initial feeding is significant $(P<0.05)$ for the growth and survival rate of larvae. The highest total length (TL) and survival rate of 43 days old larvae was at treatment (B) $(29.3 \mathrm{~mm} \pm 0.36 \mathrm{~mm}$ and $2.61 \% \pm 0.21 \%)$ and the lowest was (A) $(2.07 \mathrm{~mm} \pm 0.25 \mathrm{~mm}$ and $0.85 \% \pm 0.13 \%)$. These results show that initial aplication of artificial diet on D-10 old larvae is the best for larval rearing of Blacksaddled coral grouper.

KEYWORDS: $\quad$ blacksaddled coral grouper, larvae, artificial diet

\section{PENDAHULUAN}

Ikan kerapu raja sunu (Plectropomus laevis) merupakan komoditas ekspor yang bernilai ekonomis

\# Korespondensi: Balai Besar Penelitian dan Pengembangan Budidaya Laut. Jl. Br. Gondol, Kec. Gerokgak Kab. Buleleng, Kotak Pos 140, Singaraja, Bali 81101, Indonesia.

Tel.: + (0362) 92272

E-mail: bedjoselamet@yahoo.co.id tinggi di pasar Asia. Saat ini stok ikan kerapu raja sunu di alam sudah sangat langka sebagai akibat penangkapan yang berlebihan. Usaha ke arah budidaya ikan ini perlu dilakukan dalam rangka perlindungan populasinya di alam, pemenuhan kebutuhan pasar dan diversifikasi usaha budidaya ikan kerapu. Usaha pembenihan ikan kerapu raja sunu perlu dilakukan dalam rangka pemenuhan kebutuhan benih pada upaya budidayanya. 
Penelitian pemeliharaan induk ikan kerapu raja sunu di bak telah berhasil pada tahun 2010 (Slamet et al., 2010). Pemeliharaan larva kerapu raja sunu dengan pakan alami rotifer dan Artemia tanpa pengkayaan belum menghasilkan yuwana (Slamet et al., 2011). Peningkatan nutrisi jasad pakan pada pemeliharaan larva stadia awal dengan penambahan frekuensi pemberian fitoplankton Nannochloropsis sp., dapat menghasilkan yuwana, namun sintasan yang diperoleh masih lebih rendah dari 0,1\% (Slamet et al., 2012). Perbaikan pembenihan ikan kerapu raja sunu melalui aplikasi bakteri probiotik pada media pemeliharaan larva juga dapat meningkatkan sintasan larva sampai 0,6\% (Slamet, et al., 2013).

Dalam pemeliharaan larva kerapu raja sunu ketersediaan pakan alami seperti rotifer (Brachionus sp.), Artemia dan naupli copepoda (Acartia sp.) dengan nutrisi yang memadai sangat diperlukan. Namun dalam penyediaannya sering mengalami kendala karena produksinya sangat tergantung pada kondisi cuaca dan kandungan gizinya terkadang kurang memenuhi kebutuhan nutrisi larva. Oleh karenanya pada stadia umur larva tertentu, peranan pakan a!ami perlu dilengkapi dengan pakan buatan karena penyediaan pakan buatan lebih praktis dan komposisi nutriennya dapat disesuaikan dengan kebutuhan tubuh larva itu sendiri (Zonneveld et aI., 1991). Penggunaan pakan buatan (pelet) untuk melengkapi nutrisi pakan alami perlu dikembangkan. Pemberian pakan alami dan pakan buatan sesuai dengan kemampuan pencernaan larva kerapu, dapat meningkatkan sintasan larva (Melianawati et al., 2010). Penggunaan pakan buatan sebagai pelengkap dan bahkan substitusi pakan alami telah berhasil dilakukan pada larva beberapa spesies kerapu, seperti pada larva kerapu bebek, Cromileptes altivelis (Sugama et al., 1998), larva kerapu macan, Epinephelus fuscoguttatus (Setiadharma et al., 1999), dan larva kerapu batik (Epinephelus microdon) (Marzuqi et al., 2001).

Menurut Giri et al. (1993), pakan buatan harus diberikan tepat waktu agar pakan dapat dicerna dan diserap larva secara efisien sesuai dengan perkembangan stadiumnya. Setiap jenis ikan mempunyai stadium perkembangan larva yang berbeda sehingga waktu awal pemberian pakan buatan diduga juga berbeda. Hingga saat ini pemberian pakan buatan secara tepat dalam pemeliharaan larva kerapu raja sunu belum diketahui. Pada pemeliharaan larva kerapu bebek, Cromileptes altivelis pemberian pakan buatan yang terlalu dini (umur 10 hari) cenderung menghasilkan pertumbuhan yang lebih lambat dan sintasan yang lebih rendah dibandingkan dengan pemberian pada umur 15 dan 20 hari. Hal ini sangat berkaitan dengan perkembangan system pencernaan larva pada stadia awal yang masih sederhana dan belum berfungsi secara sempurna, sehingga proses pencernaan pakan buatan belum dapat dilakukan secara optimal dan mengakibatkan pertumbuhan yang lambat dan sintasan yang rendah (Marzuqi et al., 2001). Sebaliknya pemberian pakan buatan yang terlambat (lebih dari umur 25 hari) dapat mengakibatkan tingkat kematian yang tinggi yang disebabkan kurangnya kandungan nutrisi dalam pakan alami untuk memenuhi kebutuhan hidup larva (Kawahara et al., 2000). Pemberian pakan buatan pada larva ikan kerapu bebek sudah dimulai dari D-7 (Ismi \& Asih, 2014), pada larva kerapu sunu (Plectropoma leopardus) dimulai dari D-10 (Suwirya et al., 2006) dan pada larva kerapu macan mulai umur 13 hari (Melianawati, 2009). Dari hal tersebut, perlu dilakukan penelitian tentang waktu awal pemberian pakan buatan dalam pemeliharaan larva kerapu raja sunu yang efektif untuk menunjang sintasan larva.

\section{BAHAN DAN METODE}

Pemeliharaan larva kerapu raja sunu menggunakan bak beton volume $6 \mathrm{~m}^{3}$ yang diisi air laut yang telah melalui saringan pasir dan filter bag. Pada setiap bak ditebar larva yang baru menetas dengan kepadatan 10 ekor/liter. Penelitian pemeliharaan larva dilakukan sampai larva berumur 43 hari. Pada bak pemeliharaan dilengkapi dengan sistem aerasi dan sistem sirkulasi air laut. Perlakuan yang diuji adalah waktu awal pemberian pakan buatan (pelet) yang berbeda yaitu (a) mulai umur 7 hari (standard larva kerapu bebek), (b) mulai umur 10 hari (standar larva kerapu sunu). dan (c) mulai umur 13 hari (standar larva kerapu macan). Masing-masing perlakuan terdiri atas 3 kelompok waktu yang berbeda. Rancangan penelitian yang digunakan adalah rancangan acak kelompok (RAK). Pada semua perlakuan, diberikan Nanochloropsis dengan kepadatan $10^{5} \mathrm{sel} / \mathrm{mL}$ pada larva mulai umur 1 hari sampai 35 hari. Pakan berupa rotifer diberikan pada larva mulai umur 2 sampai 35 hari dengan kepadatan 10-20 ind./mL. Pakan buatan berupa mikro pelet komersial khusus untuk larva ikan kerapu diberikan sesuai perlakuan, dengan ukuran disesuaikan dengan perkembangan umur larva. Pemberian pakan buatan dilakukan 5 kali per hari, dengan cara menaburkan sampai merata ke seluruh permukaan air media pemeliharaan larva. Naupli Artemia mulai diberikan pada larva D-15 sampai D-40 dengan kepadatan 0,10,5 ind./mL. Sirkulasi air media dilakukan mulai larva umur 7 hari sebanyak 5\% volume media/hari dan selanjutnya sirkulasi air media dilakukan dengan peningkatan $5 \%$ per hari.

Parameter yang diamati meliputi perkembangan morfologi, panjang total, sintasan, dan isi lambung larva. Pengambilan sampel larva masing-masing sebanyak 10 ekor dilakukan setiap hari mulai umur 1 
hari untuk diamati morfologinya. Pengamatan panjang total larva dilakukan menggunakan mikroskop yang dilengkapi dengan mikrometer. Pada larva mulai umur 3 hari juga dilakukan pembedahan terhadap lambung larva dan dilakukan penghitungan jumlah rotifer yang terdapat dalam lambung, menggunakan mikroskop. Sebagai data penunjang dilakukan analisa komposisi proximat (protein, lemak, serat, abu, air) dan total n3 HUFA terhadap pakan buatan yang digunakan serta pengukuran kualitas air media pemeliharaan larva antara lain suhu, DO, salinitas, pH, amoniak, fosfat, dan nitrat.

Untuk mengetahui perkembangan saluran pencernaan larva kerapu raja sunu umur 7, 10, dan 13 hari dilakukan pembuatan preparat irisan (histologi) larva. Sampel larva difiksasi dengan larutan bouin selama 1 jam kemudian dipindahkan ke dalam botol sampel yang berisi larutan alkhohol 70\%. Proses selanjutnya adalah clearing dengan menggunakan larutan alkhohol bertingkat, diembeding dengan parafin, diiris secara longiturdinal dengan mikrotom yang mempunyai ketebalan 6-8 ìm dan pewarnaan dengan larutan Harris'. Untuk mengetahui pengaruh waktu awal pemberian pakan buatan terhadap perkembangan larva kerapu raja sunu, data pertumbuhan panjang dan sintasan larva dianalisis ANOVA dan uji beda nyata terkecil (LSD).

\section{HASIL DAN BAHASAN}

Pertumbuhan larva pada pemeliharaan dengan perlakuan penambahan pakan buatan (pelet) mulai umur 7 hari (D-7) (A), mulai D-10 (B), dan mulai D-13 (C), pada semua perlakuan telah mencapai fase yuwana pada umur 43 hari dengan ukuran panjang total 27,0 $\pm 0,25 \mathrm{~mm}$ pada perlakuan $\mathrm{A}, 29,3 \pm 0,36 \mathrm{~mm}$ pada perlakuan B dan 28,0 $\pm 0,85 \mathrm{~mm}$ pada perlakuan perlakuan C (Tabel 1). Dari Tabel 1, Gambar 1, 2, dan 3 terlihat bahwa waktu awal pemberian pakan buatan memberikan pengaruh terhadap pertumbuhan larva (panjang total, panjang duri punggung dan duri dada). Pakan buatan yang diberikan sebelum larva berumur 10 hari diduga belum dapat dicerna secara optimal karena sistem pencernaan larva yang belum sempurna. Sedangkan pemberian pakan mulai umur 13 hari (perlakuan C) diduga agak terlambat, sehingga terjadi kekurangan nutrisi yang mengakibatkan lambatnya pertumbuhan larva dan sintasan yang lebih rendah. Umur larva 10 hari merupakan waktu awal pemberian pakan buatan yang paling tepat bagi larva kerapu raja sunu, yang diindikasikan dengan pertumbuhan panjang total, panjang duri punggung dan duri dada larva yang lebih tinggi (Tabel 1, Gambar 1, 2, dan 3). Kelangsungan hidup larva sampai ke fase yuwana (D43) menunjukkan bahwa tertinggi pada perlakuan B $(2,61 \% \pm 0,21 \%)$ disusul kemudian pada perlakuan $\mathrm{C}$
$(1,55 \% \pm 0,18 \%)$ dan terendah pada perlakuan $\mathrm{A}(0,85$ $\pm 0,13 \%)$. Hal ini diduga merupakan hasil interaksi antara jenis dan kombinasi pakan yang sesuai dengan kebutuhan larva, serta kapasitas fungsional sistem pencernaan larva (Suwirya et al., 2002). Waktu awal pemberian pakan buatan yang tepat diduga mampu menghasilkan perbandingan yang tepat antara pakan buatan, Artemia, dan rotifer dalam lambung larva untuk menghasilkan nilai nutrisi yang optimal bagi pertumbuhan larva, sehingga dapat meningkatkan pertumbuhan. Perbedaan waktu awal pemberian pakan buatan akan berpengaruh terhadap aktivitas enzim pencernaan larva (Melianawati, 2009). Hasil penelitian Melianawati et al. (2010), menunjukkan bahwa penambahan pakan buatan yang berkadar protein $50 \%$ pada larva kerapu bebek mulai umur 8 dan 13 hari mampu menstimulir peningkatan aktivitas enzim protease. Pada pemeliharaan larva ikan laut membutuhkan asam lemak esensial yang cukup untuk pertumbuhan, pembentukan sel dan jaringan, energi, serta memelihara integritas biomembran (Watanabe, 1988). Hal ini dapat dipenuhi melalui pengkayaan pakan alami atau penambahan pakan buatan untuk melengkapi nutrisi yang dibutuhkan oleh larva (Veloza et al., 2006; Bell et al., 2007).

Menurut Suryanti (2002), penyerapan protein dari pakan buatan pada kerapu tikus (C. altivelis) dimulai pada saat larva berumur 14-22 hari, yang ditandai dengan sekresi tripsin oleh epitel usus bagian belakang yang mengaktifasi enzim pencernaan. Selanjutnya dikatakan bahwa jumlah enzim pencernaan (protease, lipase, dan karbohidrase) yang dihasilkan sangat tergantung dari jenis makanan yang diterima oleh usus. Pakan buatan juga dapat merangsang sekresi enzim tetapi pada kasus ini larva belum siap memproduksi enzim. Berbeda dengan pakan alami yang memang dalam tubuhnya sendiri sudah ada enzim sehingga dapat mengalami autolysis (tanpa perlu enzim dari larva). Tingkat kecernaan pakan yang rendah mengakibatkan lambatnya pertumbuhan larva, sehingga pada fase awal larva (sebelum berumur 10 hari), pemberian pakan alami lebih dianjurkan karena tingkat kecernaan pakan alami yang lebih tinggi dibandingkan dengan pakan buatan. Kelebihan lain dari pakan alami adalah karena pakan alami banyak mengandung enzim yang dapat membantu proses pencernaan dalam saluran pencernaan larva (Effendie, 1997). Suryanti (2002) melaporkan bahwa efektivitas penyerapan nutrien dari pakan alami disebabkan pada pakan alami banyak terdapat asam amino bebas (FAA) yang langsung dapat diserap.

Pemberian pakan buatan yang terlalu dini tidak hanya berakibat pada tingkat kecernaan pakan yang rendah oleh larva, tetapi juga mengurangi jumlah pakan alami yang mungkin dapat tertampung oleh lambung 
Tabel 1. Sintasan dan panjang total larva ikan kerapu raja sunu (Plectropomus laevis) pada pemeliharaan dengan perlakuan penambahan pakan buatan mulai D-7 (A), mulai D-10 (B) dan mulai D-13 (C)

Table 1. Survival rate and total length of black saddled coral grouper (Plectropomus laevis) larvae on rearing by initial artificial feed start on $D-7$ (A), D-10 and D-13 (C)

\begin{tabular}{lccc}
\hline $\begin{array}{c}\text { Pemberian pakan buatan } \\
\text { Artificial feed }\end{array}$ & $\begin{array}{c}\text { Sintasan } \\
\text { Survival rate }(\%)\end{array}$ & $\begin{array}{c}\text { Panjang total awal D-0 } \\
\text { Initial total length D-0 }(\mathbf{m m})\end{array}$ & $\begin{array}{c}\text { Panjang total akhir (D-43) } \\
\text { Final total length D-43 }(\mathbf{m m})\end{array}$ \\
\hline $\begin{array}{l}\text { Mulai D-7 (A) } \\
\text { Start D-7 (A) }\end{array}$ & $0.85 \pm 0.13^{\mathrm{a}}$ & $1.68 \pm 0.74$ & $27.0 \pm 0.25^{\mathrm{a}}$ \\
$\begin{array}{l}\text { Mulai D-10 (B) } \\
\text { Start D-10 (B) }\end{array}$ & $2.61 \pm 0.21^{\mathrm{c}}$ & $1.68 \pm 0.74$ & $29.3 \pm 0.36^{\mathrm{b}}$ \\
Mulai D-13 (C) & $1.55 \pm 0.18^{\mathrm{b}}$ & $1.68 \pm 0.74$ & $28.0 \pm 0.85^{\mathrm{a}}$ \\
Start D-13 (C) & $\begin{array}{l}\text { Keterangan (Note): Angka pada kolom yang sama diikuti oleh huruf yang sama tidak terdapat perbedaan } \\
\text { yang nyata diantara perlakuan (In the same column followed by the same letter indicate no significant difference } \\
\text { between treatments) }\end{array}$
\end{tabular}

larva. Hal tersebut terlihat dari hasil analisis jumlah rotifer dalam lambung, sebagaimana terlihat pada Gambar 4. Diduga pelet memiliki tekstur yang lebih keras dan kaku dibandingkan dengan pakan alami, sehingga memerlukan tempat yang lebih besar pada lambung larva. Konsumsi pakan buatan oleh larva menimbulkan kecenderungan pengurangan konsumsi larva terhadap pakan alami (rotifer dan Artemia).

Konsumsi rotifer oleh larva kerapu raja sunu mulai berkurang pada umur 22 hari karena larva lebih menyukai pakan buatan dan nauplii Artemia yang ukurannya lebih besar dari rotifer. Menurut Supriatna \& Slamet (1992), kesukaan makan larva kerapu macan dipengaruhi oleh ukuran, gerakan dan penampakan pakan oleh larva. Dilaporkan juga bahwa larva kerapu macan baru efektif makan nauplii Artemia mulai umur 15 hari. Jumlah rotifer dalam lambung larva ikan kerapu raja sunu semakin meningkat seiring dengan umur larva kemudian menurun pada umur 17 sampai 21 hari (Slamet et al., 2011).

Hasil analisa komposisi proximat (protein, lemak, serat, abu, air) pakan buatan disajikan pada Tabel 2

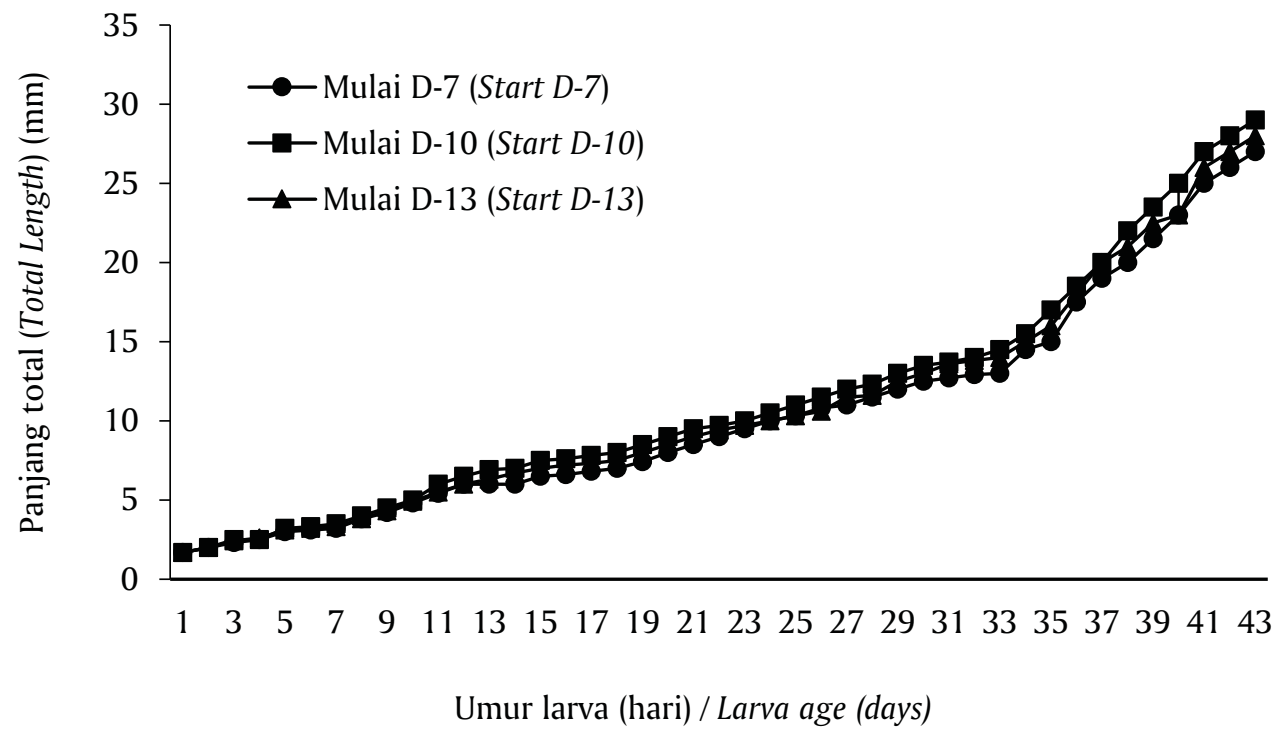

Gambar 1. Panjang total $(\mathrm{mm})$ larva ikan kerapu raja sunu (Plectropomus laevis) pada pemeliharaan dengan perbedaan waktu awal penambahan pakan buatan

Figure 1. Total length ( $\mathrm{mm}$ ) of black saddled coral grouper (Plectropomus laevis) larvae on rearing by different initial addition of artificial feed 


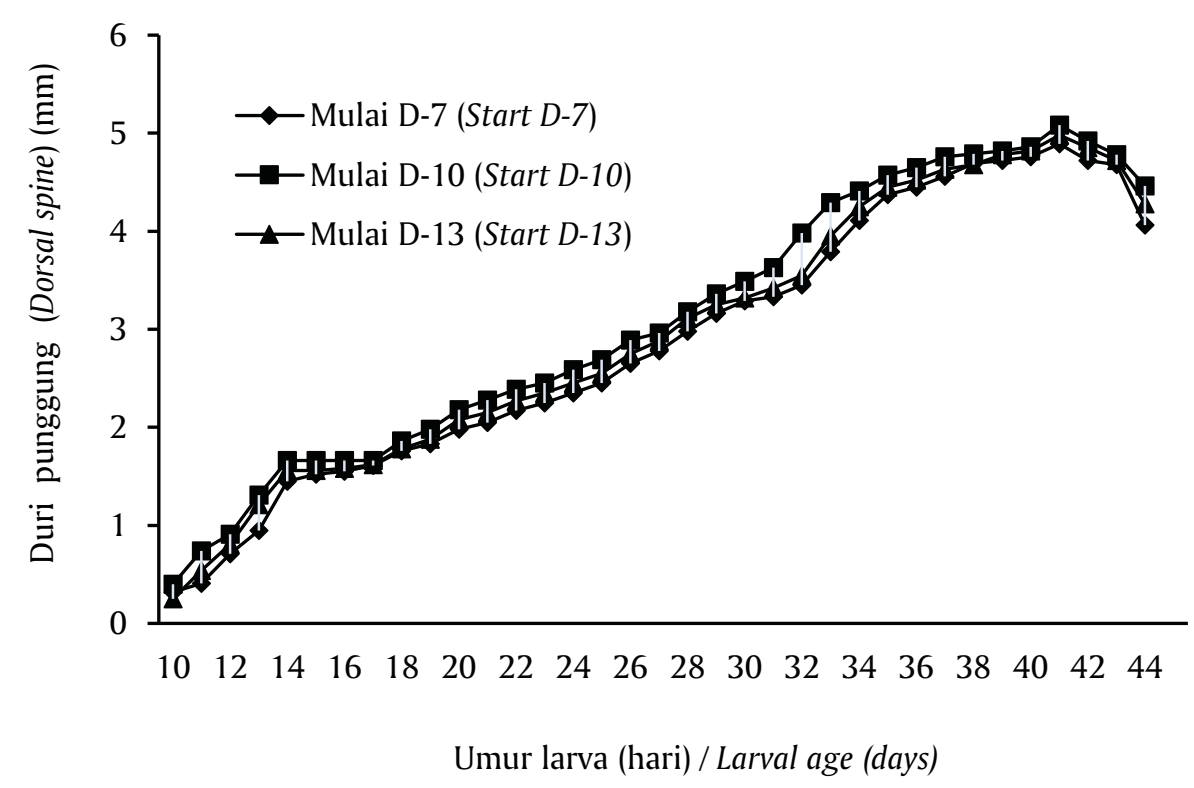

Gambar 2. Panjang duri punggung $(\mathrm{mm})$ larva ikan kerapu raja sunu (Plectropomus laevis) pada pemeliharaan dengan perbedaan awal penambahan pakan buatan

Figure 2. Dorsal spine length ( $\mathrm{mm}$ ) of blacksaddled coral grouper (Plectropomus laevis) larvae on rearing by different initial addition of artificial feed

dan total n-3 HUFA pada Tabel 3. Aslianti \& Priyono (2003) melaporkan komposisi proksimat rotifer dan Artemia seperti pada Tabel 2. Dari data tersebut terlihat bahwa pakan buatan mempunyai kandungan protein yang lebih tinggi dibanding rotifer dan Artemia. Aslianti \& Priyono (2005) melaporkan kandungan asam lemak rotifer dan Artemia seperti pada Tabel 3, yang menunjukkan bahwa kandungan total n-3 HUFA pakan buatan adalah lebih tinggi dibanding pakan alami (rotifer dan Artemia). Marzuqi et al. (2001) melaporkan, bahwa asam lemak n-3 HUFA pada pakan buatan lebih tinggi $(36,95 \%)$ dari pada Artemia $(5,33 \%)$, namun

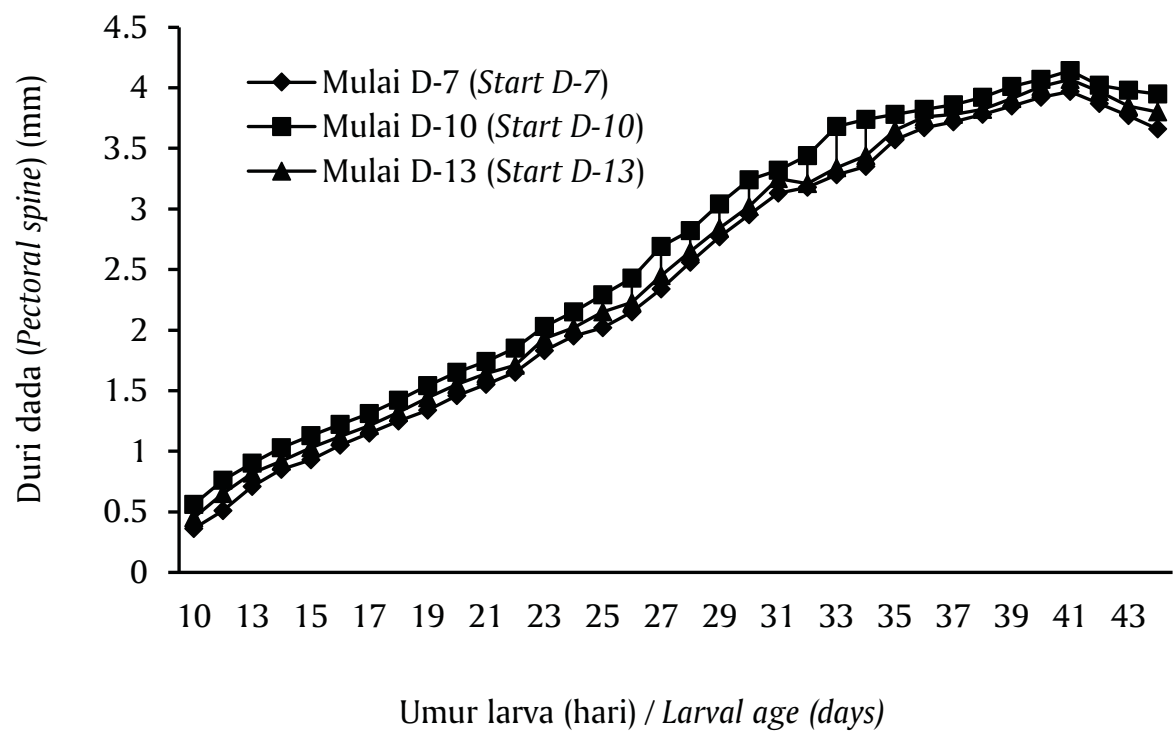

Gambar 3. Panjang duri dada (mm) larva ikan kerapu raja sunu (Plectropomus laevis) pada pemeliharaan dengan perbedaan awal penambahan pakan buatan

Figure 3. Pectoral spine length ( $\mathrm{mm}$ ) of blacksaddled coral grouper (Plectropomus laevis) larvae on rearing by different initial addition of artificial feed 


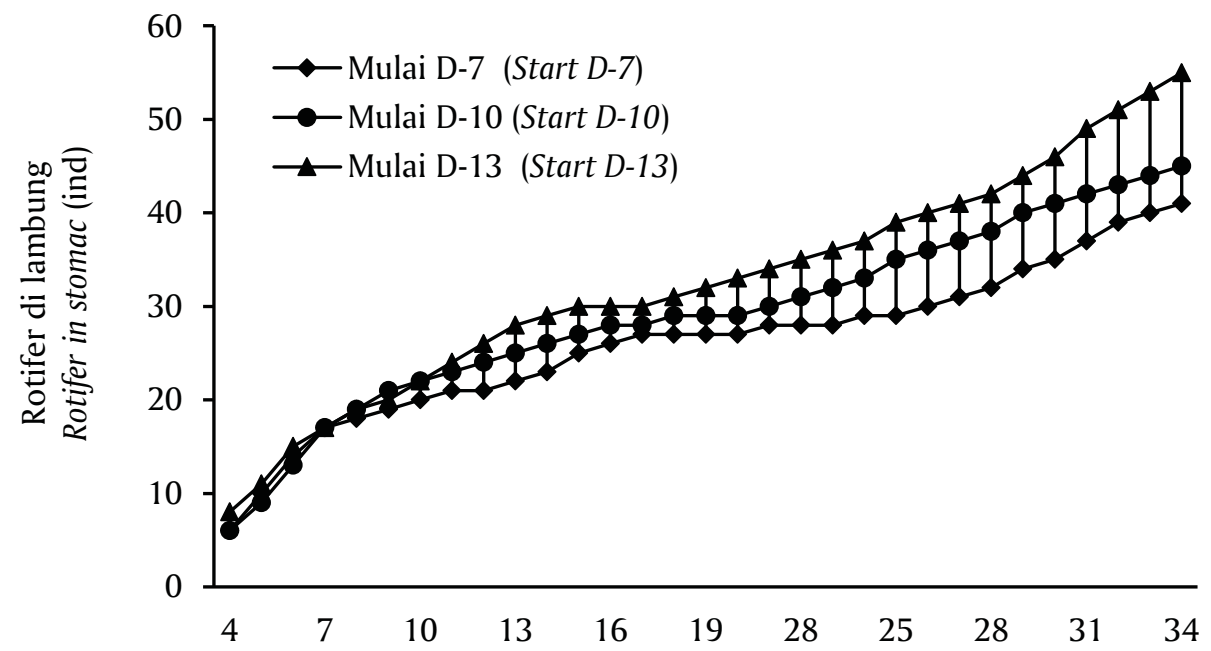

Umur larva (hari) / Larval age (days)

Gambar 4. Jumlah rotifer (ind/larva) dalam lambung larva ikan kerapu raja sunu (Plectropomus laevis) pada pemeliharaan dengan perbedaan awal penambahan pakan buatan

Figure 4. Number of rotifer in stomac (ind/larvae) of black saddled coral grouper (Plectropomus laevis) larvae on rearing by different initial addition of artificial feed

demikian jika larva hanya diberi pakan buatan saja akan menghasilkan sintasan dan pertumbuhan yang lebih rendah, sedangkan pemberian pakan buatan yang dikombinasikan dengan pakan alami (rotifer dan Artemia) menghasilkan sintasan dan pertumbuhan yang lebih baik. Marzuqi et al. (2001), mengungkapkan bahwa sintasan larva kerapu sangat dipengaruhi oleh faktor nutrisi yang lengkap dan seimbang sesuai dengan kebutuhan larva ikan. Menurut Setiadharma et al. (1999) bahwa pakan buatan sudah mulai diberikan pada larva kerapu macan umur 13 hari sedangkan menurut Aslianti \& Priyono (2003) mulai D-7. Pada kerapu bebek (C. altivelis) umur 17 hari merupakan waktu awal yang paling tepat untuk pemberian pelet mikro (Kawahara et al., 2000). Pada kerapu batik (Epinephelus microdon) pemberian pelet mikro mulai umur 20 hari (D-20) menghasilkan sintasan dan pertumbuhan serta vitalitas larva yang terbaik (Marzuqi et al., 2001). Menurut Tocher (2003), HUFA, EPA, dan DHA sangat penting pada larva ikan. Asam lemak yang berfungsi untuk metabolik dan komponen dalam membrane sel meliputi eikosapentanoat (EPA) dan asam dokosa-heksaenoat (DHA) (Seiffert et al., 2001).

Saluran pencernaan larva kerapu raja sunu pada umur D-7 belum begitu berkembang (Gambar 5a) di mana dindingnya baru mulai menebal dan terbentuk microfili pada permukaan usus yang mengindikasikan penyerapan makanan mulai optimal, lapisan intestine

Tabel 2. Komposisi proximat rotifer (Brachionus plicatilis), Artemia salina dan pelet

Table 2. Proximate composition of rotifer (Brachionus plicatilis), Artemia salina, and pellet

\begin{tabular}{lccc}
\hline $\begin{array}{c}\text { Jenis nutrisi } \\
\text { Nutrients type }\end{array}$ & $\begin{array}{c}\text { Brachionus plicatilis } \\
\text { Brachionus plicatilis (\%) }\end{array}$ & $\begin{array}{c}\text { Artemia salina } \\
\text { Artemia salina (\%) }\end{array}$ & $\begin{array}{c}\text { Pelet } \\
\text { Pelet (\%) }\end{array}$ \\
\hline Protein (Protein) & 45.88 & 53.20 & 66.5 \\
Lemak (Fat) & 13.00 & 18.32 & 15.5 \\
Serat (Fiber) & - & 4.91 & 4.23 \\
Abu (Ash) & 18.94 & 6.66 & 12.5 \\
Air (Water) & - & 15.15 & 6.5 \\
\hline
\end{tabular}

Keterangan (Note): ${ }^{1)}$ Aslianti \& Priyono (2003) 
Tabel 3. Kandungan asam lemak rotifer (Brachionus plicatili), Artemia salina, dan pelet

Table 3. Fatty acid content of rotifer (Brachionus plicatilis) and Artemia salina

\begin{tabular}{lccc}
\hline $\begin{array}{c}\text { Asam lemak } \\
\text { Fatty acids }\end{array}$ & $\begin{array}{c}\text { Brachionus plicatilis } \\
\text { Brachionus plicatilis (\%) }\end{array}$ & $\begin{array}{c}\text { Artemia salina } \\
\text { Artemia salina (\%) }\end{array}$ & $\begin{array}{c}\text { Pelet } \\
\text { Pellet (\%) }\end{array}$ \\
\hline 14:00 & 4.94 & 0.320 & - \\
$16: 00$ & 20.51 & 13,426 & - \\
$16: 01$ & 22.11 & - & - \\
$18: 01$ & 12.83 & 41,975 & - \\
$18: 2 \mathrm{n}-6$ & 6.13 & - & - \\
$18: 3 n-3$ & 2.02 & 38,844 & - \\
$20: 3 n-3$ & 4.27 & 1,243 & - \\
$20: 5 n-3$ (EPA) & 13.02 & 3,172 & - \\
$22: 6 n-3$ (DHA) & 5.00 & 0 & - \\
$22: 1 \mathrm{n}-9$ & - & 0.012 & - \\
$22: 5 n-3$ & - & -0.998 & - \\
Total n-3 HUFA & 24.13 & 44.25 & $\left.38.5^{*}\right)$ \\
\hline
\end{tabular}

Keterangan (Note):

${ }^{1)}$ Aslianti \& Priyono (2005)

${ }^{\circ}$ Hasil analisis total n-3 HUFA (from analysis of $n-3$ HUFA)

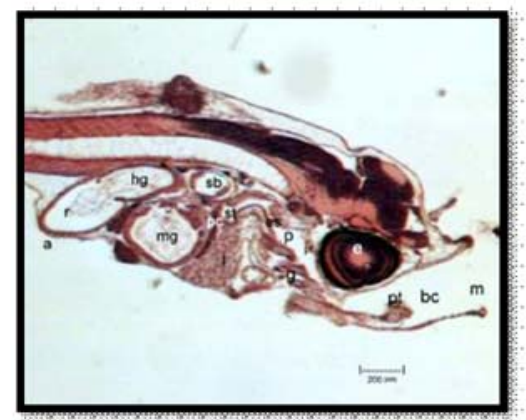

a: D-7

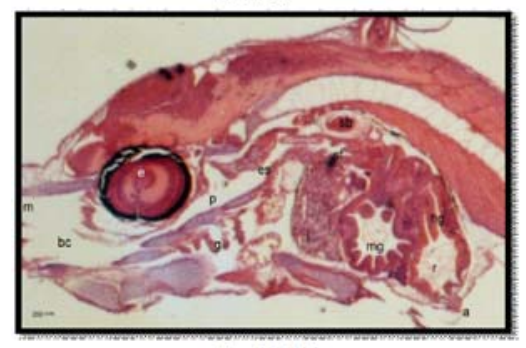

b: D-10

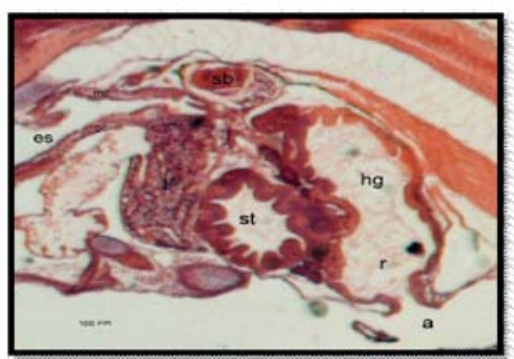

c: D-13
Keterangan (Note):

e : mata (eye)

$\mathrm{M}$ : mulut (mouth)

Bc : rongga mulut (buccal cavity)

p : tenggorokan (pharing)

$\mathrm{g}$ : insang (gill)

$\mathrm{Sb}$ : gelembung renang (swim bladder)

Es : kerongkongan (esophagus)

st : lambung (stomact)

1 : hati (liver)

mg : usus tengah (midgut)

hg : usus bagian belakang (hindgut)

$\mathrm{r} \quad$ : dubur (rectum)

a : anus (anus)

$\mathrm{Sb}$ : gelembung renang (swim bladder)

G : sel goblet (goblet cell)

Mc : sel mucosa (mucosa cell)

$\mathrm{i} \quad$ : usus (intestine)

Gambar 5. Irisan organ pencernaan larva kerapu raja sunu (Plectropoma laevis) (a: D-7, b: D-10, dan c: D-13)

Figure 5. Section of digestive tract of black sudled Black saddled coral grouper (Plectropoma laevis) ( $a$ : D-7, $b: D-10$, and $c: D-13$ ) 
melipat, lipid vocuola mulai terbentuk yang mengindikasikan adanya proses pencernaan. Gelembung renang terbentuk dan pada bagian mulut baru terbentuk sel epitel berlapis yang akan membentuk taste bud. Pada larva umur D-10 (Gambar 5b) dan D-13 (Gambar 5c), terlihat bahwa saluran pencernaan larva telah terbentuk phili-phili usus yang sudah sempurna. Pada D10 dan D13 sel goblet dan sel mucosa sudah terlihat pada farink dan esophagus. Menurut Suryanti \& Priyadi (2002), pemberian pakan buatan harus disesuaikan dengan kesiapan larva secara fisiologis karena pakan buatan terdiri dari nutrien yang mempunyai struktur molekul yang kompleks dan tidak mengandung enzim sehingga diperlukan ketersediaan enzim untuk mencernanya.

Sel goblet mensekresikan mucosa yang berfungsi untuk mempermudah proses penelanan makanan di esophagus (Watanabe, 1984). Pada larva ikan kerapu bebek (Cromileptes altivelis), jumlah sel goblet yang terdapat pada esophagus, midgut, dan hidgut akan terus bertambah jumlahnya seiring dengan perkembangan sistem pencernaan dan berhenti hingga terbentuknya kelenjar pencernaan (gastric gland) (Andriyanto \& Muzaki, 2013). Sebelum gastric gland terbentuk, proses pencernaan dibantu oleh supranuclear vacuola yang jumlahnya terus berkurang hingga terbentuknya gastric glands (Watanabe, 1984).

Perkembangan saluran pencernaan berlangsung secara bertahap dan setelah ikan mencapai ukuran atau umur tertentu maka saluran pencernaannya akan mencapai kesempurnaan. Perkembangan struktur pencernaan tersebut diikuti pula oleh perkembangan enzim pencernaan. Struktur sistem pencernaan yang masih sederhana pada larva berkorelasi pula dengan rendahnya produksi enzim pencernaan (Dabrowski \& Glogowski, 1977).

Hasil pengukuran kualitas air pada ketiga perlakuan pemeliharaan larva relatif sama dan secara umum pada kisaran yang layak untuk pemeliharaan larva ikan kerapu (Tabel 4).

\section{KESIMPULAN}

Perbedaan waktu awal pemberian pakan buatan memberikan pengaruh yang nyata terhadap pertumbuhan dan sintasan larva kerapu raja sunu. Waktu awal pemberian pakan buatan dimulai dari D10 menghasilkan pertumbuhan dan sintasan larva kerapu raja sunu umur 43 hari tertinggi yaitu panjang total 29,3 $\mathrm{mm} \pm 0,36 \mathrm{~mm}$ dan sintasan $2,61 \% \pm 0,21 \%$.

\section{UCAPAN TERIMA KASIH}

Penulis mengucapkan terima kasih kepada Ahmad Gufron Arief dan Made Suparya yang telah membantu dalam penelitian ini.

\section{DAFTAR ACUAN}

Andriyanto, W., \& Muzaki, A. (2013). Diferensiasi organ pencernaan larva kerapu bebek turunan ke-3 dan beberapa aktivitas enzim yang terkait. J. Ris. Akuakultur, 8(1), 51-63.

Aslianti, T., \& Priyono, A. (2003). Peningkatan nutrisi rotifer (Brachionus sp.) sebagai pakan alami pada pemeliharaan larva kerapu lumpur, Epinephelus coioides. Prosiding penerapan teknologi tepat guna dalam mendukung agribisnis. BPTP Yogyakarta, hlm. 239-246.

Aslianti, T., \& Priyono, A. (2005). Respon awal larva kerapu lumpur, Epinephelus coioides terhadap pakan buatan. Aquacultura Indonesiana, 6(2), 67-77.

Bell., M.V., Dick, J.R., Anderson, T.R., \& Pond, D.W. (2007). Application of liposome and stable isotope tracer techniques to study polyunsaturated fatty acid biosynthesis in marine zooplankton. J. Plankton Research, 29, 41-422.

Dabrowski, K., \& Glogowski, J. (1977). Studies on the role of exogenous proteolytic enzymes in di-

Tabel 4. Kualitas air pemeliharaan larva selama penelitian

Table 4. Water quality on larval rearing during experiment

\begin{tabular}{lccc}
\hline \multirow{2}{*}{ Parameter } & \multicolumn{3}{c}{ Perlakuan (Treatment) } \\
\cline { 2 - 4 } & $\mathrm{A}$ & $\mathrm{B}$ & $\mathrm{C}$ \\
\hline Suhu (Temperature) $\left({ }^{\circ} \mathrm{C}\right)$ & $27-30$ & $27-30$ & $27-30$ \\
Salinitas (Salinity) $(\mathrm{ppt})$ & $33.5-34.5$ & $33.5-34.5$ & $33.5-34.5$ \\
$\mathrm{pH}$ & $8.1-8.4$ & $8.1-8.4$ & $8.1-8.4$ \\
Oksigen terlarut (Disolve oxygen) $(\mathrm{mg} / \mathrm{L})$ & $5.2-6.3$ & $5.3-6.4$ & $5.4-6.5$ \\
Amonia (Ammonium) $(\mathrm{mg} / \mathrm{L})$ & $0.035-0.268$ & $0.035-0.195$ & $0.032-0.175$ \\
Fosfat (Phosphate) $(\mathrm{mg} / \mathrm{L})$ & $0.088-0.285$ & $0.076-0.215$ & $0.065-0.185$ \\
Nitrat (Nitrate) $(\mathrm{mg} / \mathrm{L})$ & $0.143-1.95$ & $0.143-1.84$ & $0.143-1.76$ \\
\hline
\end{tabular}


gestion processes in fish. Hydrobiologia, 54(2), 129-134.

Effendie, M.I. (1997). Biologi Perikanan. Yayasan Pustaka Nusantara. Yogyakarta, $126 \mathrm{hlm}$.

Giri, N.A., Marzuqi, M., Jufri, \& Kuma, C. (1993). Pengaruh perbedaan waktu awal pemberian pakan buatan terhadap pertumbuhan dan sintasan larva udang windu (P. monodon). J. Pen. Budidaya Pantai, 9(2), 81-88.

Ismi, S., \& Asih, Y.N. (2014). Peningkatan jumlah dan kualitas produksi benih ikan kerapu melalui pengkayaan pakan alami. J. Ilmu dan Teknologi Kelautan Tropis, 6(2), 401-414.

Kawahara, S., Setiadi, I., Ismi, S., Tridjoko, \& Sugama, K. (2000). Kunci Keberhasilan Produksi masal Juvenil Kerapu Bebek (Cromileptes altivelis). Lolitkanta-JICA Booklet, No. 11. $16 \mathrm{hlm}$.

Marzuqi, MGiri, ., I N.A., Setiawati, K.M., \& Suwirya, K. (2001). Pemeliharaan larva kerapu batik (Epinephelus microdon) dengan awal pemberian pakan mikro pada umur yang berbeda. Teknologi Budidaya Laut dan Pengembangan Sea Farming di Indonesia. Dept. Kelautan dan Perikanan-JICA, hlm. 190-196.

Melianawati, R. (2009). Aktivitas enzim pencernaan larva ikan kerapu macan (Epinephelus fuscoguttatus Forsskal, 1775) terkait dengan perbedaan jenis pakan. Thesis. Program Pascasarjana Universitas Gadjah Mada, $165 \mathrm{hlm}$.

Melianawati, R., Andamari, R., \& Setyadi, I. (2010). Identifikasi profil enzim pencernaan untuk optimasi oemanfaatan pakan dalam usaha budidaya ikan kerapu bebek (Cromileptes altivelis). Laporan akhir program insentif peningkatan kemampuan peneliti dan perekayasa DRN Kementerian Negara Riset dan Teknologi, $28 \mathrm{hlm}$.

Seiffert, M.E.B., Cerqueira, V.R., \& Madureira, L.A.S. (2001). Effect of dietary (n-3) highly unsaturated fatty acid on growth and survival rate of snook (Centropomus paralelus, pisces : Centropomidae) larvae during first feeding. Brazilian J. of Medical and Biological Research, 34, 645-651.

Setiadharma, T., Aslianti, T., \& Tridjoko. (1999). Penggunaan pakan buatan dengan perbedaan frekuensi pemberian terhadap sintasan dan keragaan larva kerapu macan (Epinephelus fuscoguttatus). Prosiding Seminar Nasional Penelitian dan Diseminasi Teknologi Budidaya Laut dan Pantai. Jakarta, hlm. 269-271.

Slamet, B., Suwirya, K., Setiadi, I., Melianawati, R., \& Andamari, R. (2010). Observation on natural spawning of black saddled coral grouper (Plectropoma laevis) in captivity. International Con- ference of Acuaculture Indonesia. Surabaya, 2010. p. 126-131.

Slamet, B., Suwirya, K., Melianawati, R., Ismi, S., \& Andamari, R. (2011). Pengamatan perkembangan morfologi, penyerapan energi endogenous, dan isi perut larva ikan kerapu raja sunu (Plectropoma laevis). Prosiding Forum Inovasi Teknologi Akuakultur 2011, hlm. 1217-1223.

Slamet, B., Suwirya, K., Melianawati, R., Ismi, S., \& Asih, Y.N. (2012). Pemeliharaan larva ikan kerapu raja sunu (Plectropoma laevis) dengan perbedaan frekuensi pemberian green wáter Nannochloropsis sp. Prosiding Indoaqua-Forum Inovasi Teknologi Akuakultur 2012, hlm. 149-152.

Slamet, B., Suwirya, K., Melianawati, R., Ismi, S., \& Andamari, R. (2013). Perbaikan pembenihan ikan kerapu raja sunu (Plectropoma laevis) melalui aplikasi pemberian bakteri probiotik pada media pemeliharaan larvanya. Prosiding Forum Inovasi Teknologi Akuakultur 2011, hlm. 817-823.

Sugama, K., Wardoyo, Rohaniawan, D., \& Matsuda, H. (1998). Teknologi perbenihan ikan k e r a p u tikus, Cromileptes altivelis. Prosiding Seminar Teknologi Perikanan Pantai. Denpasar, 6-7 Agustus 1998, hlm. 80-88.

Supriatna, A., \& Slamet, B. (1992). Kelangsungan hidup dan petumbuhan larva kakap putih, Lates calcarifer yang diberi pakan buatan dan pakan alami. Jurnal Penelitian Budidaya Pantai, 8(5), 15-21.

Suryanti, Y. (2002). Peran asam amino dalam fisiologi nutrisi pada awal kehidupan ikan. W a $r$ t a Penelitian Perikanan Indonesia, 8(4), 19-23.

Suryanti, Y., \& Priyadi, A. (2002). Penentuan saat awal pemberian pakan buatan dan hubungannya dengan perkembangan aktivitas enzim pencernaan pada benih ikan baung (Mystus nemurus CV.). Jurnal Penelitian Perikanan Indonesia, 8(5), 37-42.

Suwirya, K., Wardoyo, \& Giri, I N.A. (2002). Pengaruh asam lemak esensial terhadap sintasan dan vitalitas larva kerapu bebek (Cromileptes altivelis). J. Pen. Perikanan Indonesia, 9(2), 15-20.

Suwirya, K., Prijono, A., Hanafi, A., Andamari, R., Melianawati, R., Marzuqi, M., Sugama, K., \& Giri, I N.A. (2006). Pedoman teknis pembenihan ikan kerapu sunu (Plectropomus leopardus). Pusat Riset Perikanan Budidaya. Jakarta, $18 \mathrm{hlm}$.

Tocher, D.R. (2003). Metabolism and function of lipid and faty acid in teleost fish. Rev. Fish Sci., 11, 107184.

Veloza, A.J., Chu, F.L.E., \& Tang, K.W. (2006). Tropic modification of essential faty acid by heterotropic protists and its effects on the faty acid composition of the copepod Acartia tonsa. Marine Biology, $148,779-788$. 
Watanabe, Y. (1984). Morphological and functional changes in rectal ephithelium cells of pond smelt during postembryonic development. Bulletin of the Japanese Society of Scientific fisheries, 50, 805-815.
Watanabe, T. 1988. Fish Nutrition and Mariculture. JICA Tex of the General Aquaculture Course, Tokyo. 233p.

Zonneveld, N., Huisman, E.A., \& Boon, J.H. (1991). Prinsip-prinsip budidaya ikan. PT Gramedia Pustaka Utama, Jakarta, $318 \mathrm{hlm}$. 